\title{
Food and sustainability at university restaurants: analysis of water footprint and consumer opinion
}

\author{
Alimentação e sustentabilidade em restaurantes \\ universitários: análise de pegada hídrica e da opinião \\ dos consumidores
}

Leideliane Kilian $^{\mathrm{a}}$

Rozane Marcia Triches ${ }^{b}$

Eliziane Nicolodi Francescato Ruiz ${ }^{\mathrm{c}}$

${ }^{a}$ Master in Agroecology and Sustainable Rural Development, Researcher, Universidade Federal da Fronteira Sul, Laranjeiras do Sul, PR, Brazil

E-mail: kilian.nutricao@gmail.com

\begin{abstract}
${ }^{b}$ PhD in Rural Development, Professor, Curso de Graduação em Nutrição e Programa de PósGraduação em Agroecologia e Desenvolvimento Rural Sustentável, Universidade Federal da Fronteira

Sul, Realeza, PR, Brazil

E-mail: rozane.triches@uffs.edu.br
\end{abstract}

c PhD in Rural Development, Professor, Departamento de Nutrição e Programa de Pós-Graduação em Desenvolvimento Rural, Universidade Federal do Rio Grande do Sul, Porto Alegre, RS, Brazil

E-mail: elizianeruiz@yahoo.com.br

doi:10.18472/SustDeb.v12n2.2021.37939

\section{RESUMO}

Objetivo: Analisar comparativamente a sustentabilidade dos cardápios ofertados por dois restaurantes universitários (RU) do estado do Paraná a partir da pegada hídrica (PH) e da opinião dos comensais. Método: A PH foi calculada com base em 46 cardápios em cada unidade, e os dados sobre os comensais foram obtidos com aplicação de questionários para 750 pessoas e realizadas análises de Mann Whitney e qui quadrado de Pearson. Resultados: As maiores médias de PH foram dos cardápios onívoros, se comparados aos vegetarianos, com o RU2 apresentando médias superiores ao RU1. Quanto à opinião dos consumidores sobre o RU1, há maior satisfação com os preços, com as opções vegetarianas e maior conhecimento sobre as compras de orgânicos e de agricultores familiares. Conclusões: O RU1 se mostra mais próximo aos pressupostos de uma dieta sustentável que o RU2, mas ambos devem rever seus cardápios em relação à $\mathrm{PH}$ e realizar trabalhos com os comensais sobre alimentação e sustentabilidade. 
Palavras-chave: Pegada hídrica. Sustentabilidade. Alimentação Coletiva. Dietas Sustentáveis. Políticas Alimentares.

\section{ABSTRACT}

Objective: Analyze comparatively the sustainability of menus developed by two university restaurants (UR) in the State of Paraná using the water footprint (WF) and the opinion of diners as parameters. Methods: WF was calculated based on 46 menus in each unit and data on diners through questionnaires for 750 people analyzed with Mann Whitney and Pearson's chi-square. Results: The highest WF averages were from omnivorous menus compared to vegetarians and UR2 had averages higher than UR1. As for the opinion of diners about UR1, there is greater satisfaction with prices, vegetarian options, and greater knowledge about organic and purchases of family farming (FF) products. Conclusions: Therefore, RU1 is closer to the assumptions of a sustainable diet than UR2, but both should review their menus concerning WF and carry out work with diners on food and sustainability.

Keywords: Water footprint. Sustainability. Institutional Nutrition. Sustainable Diets. Food Policy.

\section{INTRODUCTION}

One of the challenges of the $21^{\text {st }}$ century is to make food production viable while using fewer natural resources. It has already been pointed out that the food systems need to be repositioned so that they can supply not only food on a large scale but also quality diets (MASON; LANG, 2017).

Corroborating the discussions that intertwine food and environmental and health issues, the proposal for sustainable diets emerges. These discussions point out that the current agri-food system has consequences that can be identified in the global context in terms of nutritional and health, economic and environmental issues. According to FAO, sustainable diets are those with low environmental impact, which contribute to food and nutritional security and healthy life for future generations. Sustainable diets are protective and respectful of biodiversity and ecosystems, culturally acceptable, accessible, economically fair, nutritionally adequate, safe and healthy while optimizing natural and human resources (FAO, 2014).

Pragmatically, the criteria for measuring what a sustainable diet is are quite broad, complex and still under construction, for they require analyses of aspects related to its nutritional, environmental, social, cultural, and economic adequacy (MARTINELLI; CAVALI, 2019; MASON; LANG, 2017).

In Brazil, few academic studies have analyzed sustainable diets, although they are on the rise in European countries especially (TRICHES, 2021). There are even fewer studies using environmental criteria for this analysis, such as water, carbon, ecological and nitrogen footprints, among other parameters (GARZILLO, 2018; STRASBURG; JAHNO, 2015). Also, few studies have attempted to understand the role of the consumer or the user of collective food services to identify their perceptions and knowledge about the topic.

Hence, this study aimed to address one of the most widely used environmental footprints, namely, water footprint $x(\mathrm{WF})$, to identify the impact of food on the environment and to seek to understand the role of consumers by understanding their satisfaction, their impressions, and their knowledge about the food provided by the URs of two Federal Universities in the State of Paraná, Brazil. Thus, the analysis intended here is to use water footprint as an environmental parameter and some sociocultural and economic parameters, indicated by consumers' impressions, to compare and find which of the two sites has indicators closer to a sustainable diet.

The water footprint is an indicator of water use. It has been more widely addressed in scientific discussions after 2002 when Arjen Hoekstra (HOEKSTRA, 2002) pointed out the use of water in large production chains. Its distinctive feature is to consider the indirect use of water, for the WF of a product/food is the total volume 
of water used to produce it throughout the entire production chain. The relevance of this indicator lies in the identification of the immense amount of the planet's freshwater used for livestock and agriculture. Most of its use is for irrigation of cereals crops (BRANDÃO, 2020; TOM; FISCHBECK; HENDRICKSON, 2016).

On the other hand, considering the sustainability of food in the socio-cultural context, among other aspects, also means taking into account the opinion of consumers. For today's society, eating is not only a biological need but also a decisional process based on economic, political and cultural aspects. It is acknowledged that the consumer can act upon the process and foster a new agri-food model (PORTILHO, 2015; TRICHES, 2020; TRICHES; SCHNEIDER, 2015). Making more room for the precepts of sustainable diets requires rethinking both the reduction of the demand for certain raw materials and energy, as well as new consumption patterns, values, and levels (MASON; LANG, 2017; TRICHES, 2020).

Finally, this study uses University Restaurants from Public Universities as sites for the survey to include the role of the State and its public food programs in the promotion of sustainable food systems.

\section{METHODS}

This is a quantitative and cross-sectional study carried out at two university restaurants. It was based on official documents from the Federal Institutions of Higher Education (Ifes) regarding the UR's menus for one semester (one academic term) and the Term of Reference of the contract notice.

Regarding the choice of the cases studied, we sought to investigate two federal universities in Paraná. In the state, four Federal Universities (Ifes) operate Federal University of Paraná (UFPR), consisting of ten campuses; Federal University of Technology - Paraná (UTFPR), consisting of 13 campuses; Federal University of the Southern Frontier (UFFS), with two campuses in Paraná; and the Federal University of Latin American Integration (Unila), with one campus. Among the three remaining options, two were chosen by meeting the following criteria: a) location - Ifes geographically close to each other; and b) similar physical structure of UR, considering the total number of meals served (lunch and dinner).

Using these criteria, the UFFS's Laranjeiras do Sul campus, identified as "RU1" (RU stands for 'University Restaurant' in Portuguese), and the UTFPR's Pato Branco campus, identified as "RU2", were chosen. The UTFPR's Pato Branco campus is in the Southwest Region of the State of Paraná, 137 kilometres from the UFFS's Laranjeiras do Sul campus, which is in the Center-South region of the State of Paraná. The two Ifes are managed through an outsourcing system with a concession agreement free of charge.

The diners' data were collected through the application of structured questionnaires with questions about satisfaction (about the price paid, menus, respect for eating habits, meat protein portion, vegetarian portions) impressions (about healthy and sustainable menus) and knowledge about the provenance of the products (about organic food and FF products purchases). Convenience sampling was used, and the survey was carried out during the lunch period of a day identified as the busiest day of the week according to the UR's managers. Thus, there were 300 diners at RU1 and 450 at RU2.

For the Water Footprint assessment, data were collected from the menus ( 23 omnivorous and 23 vegetarian menus) of the first semester of 2019 of each UR, public notices for services, and restaurant production records. The water footprint of each meal was obtained through the amount of raw food per capita of each UR. The average amount per capita of each food item was obtained from the kitchen prep sheets and control records of the total amounts of each dish prepared, provided by the key personnel of the URs and divide by the number of diners at each site (300 RU1 and 400 RU2).

For RU2, which operates differently regarding the provision of the main protein dish (meats), the average amount per capita of the two options provided was obtained. On this site, diners can take both the dishes offered. The first meat protein option, which is required by the public notice, is portioned 
according to an established amount in grams. However, not all diners take this option, for there are those who prefer the second one, as well as those who take both. Therefore, we considered the average amount per capita of both options because they are made of different types of meat, such as chicken and beef, which have different water footprints.

The next step in the WF assessment was the tabulation of data, considering the multiplication of the amount per capita of each food item by its WF (litres of water per kilo of food). The WF values were obtained from the list of products' WF estimates by Mekonnen and Hoekstra (2011).

Descriptive analyses were performed to find the mean and standard deviation of the WFs for the URs and the proportions in the questionnaires applied to diners. The non-parametric Mann-Whitney test was used to verify differences between the WFs of the UR and the types of menus on these sites, i.e. omnivore and vegetarian. To verify the differences between proportions, Pearson's Chi-square test was used. These analyses were performed using the free software PSPP, and statistical significance was considered when $\mathrm{p}<0.05$.

This research was submitted and approved (number 62708716.3.0000.5564) by the Ethics Committee of the Federal University of the Southern Frontier (UFFS).

\section{RESULTS}

Regarding the WF assessment, the means of omnivore menus are significantly higher than the vegetarian menu. However, even though the mean WF of RU1 is lower than that of RU2, there were no considerable differences between the two, except for their omnivore menus (Table 1).

Table 1 | Average WF of the URs and their respective menus - The state of Paraná, 2019.

\begin{tabular}{|c|c|c|c|c|}
\hline Variable & $N$ & Mean & Standard deviation & M-W Test \\
\hline RU1 & 46 & 1641.53 & 954.44 & \multirow{2}{*}{0.24} \\
\hline RU2 & 46 & 1946.99 & 1173.43 & \\
\hline Omnivore menus & 46 & 2523.61 & 1072.62 & \multirow{2}{*}{0.000} \\
\hline Vegetarian menus & 46 & 1064.92 & 312.30 & \\
\hline Omnivore menus of RU1 & 23 & 2179.68 & 1043.71 & \multirow{2}{*}{0.005} \\
\hline Omnivore menus of RU2 & 23 & 2867.53 & 1008.30 & \\
\hline Vegetarian menus of RU1 & 23 & 1103.38 & 410.41 & \multirow{2}{*}{0.41} \\
\hline Vegetarian menus of RU2 & 23 & 1026.45 & 167.26 & \\
\hline
\end{tabular}

Source: Prepared by the authors (2019).

In the assessment of the daily WF of each site (Table 2), it was found that in the omnivore profile, whenever there is red meat, the WF is higher. On the other hand, in the vegetarian profile, the highest WFs are related to the days when the menu establishes the association of two types of legumes. In both sites, the lowest WFs refer to the days when dishes are based on textured soy protein and roasted vegetables.

For RU2 there is a wider range of comparisons since two meat protein options are analyzed in the same menu. The average portion of animal protein offered in RU1 was $164 \mathrm{~g}$, while that in RU2 was $223 \mathrm{~g}$. Besides the RU2's menu has 50\% more frequency of red meat than the RU1's. In both sites, the lowest WFs refer to the days when dishes are based on chicken, pork, or fish. 
Table 2 | Daily water footprint of URs' menus from January to July 2019 - Paraná

\begin{tabular}{|c|c|c|c|c|c|c|}
\hline \multicolumn{3}{|c|}{$\begin{array}{c}\text { Vegetarian } \\
\text { menu }\end{array}$} & \multicolumn{4}{|c|}{$\begin{array}{c}\text { Omnivore } \\
\text { menu }\end{array}$} \\
\hline Day & R.U1 & R.U2 & R.U1 & Protein option & R.U2 & Protein option \\
\hline 1 & 943 & 1,286 & 1,760 & Pork & 4,389 & Beef* \\
\hline 2 & 1,031 & 1,041 & 1,416 & Chicken & 1,799 & Chicken and egg \\
\hline 3 & 2,507 & 885 & 4,701 & Beef & 3,421 & Beef and Chicken \\
\hline 4 & 951 & 894 & 1,422 & Chicken & 3,119 & Beef and Chicken \\
\hline 5 & 766 & 965 & 1,418 & Chicken & 1,667 & Chicken and Pork \\
\hline 6 & 812 & 1,292 & 3,106 & Beef & 4,395 & Beef* \\
\hline 7 & 1,402 & 1,041 & 1,564 & Fish & 1,799 & Chicken and Egg \\
\hline 8 & 1,479 & 890 & 1,711 & Pork & 3,582 & Beef and Pork \\
\hline 9 & 1,069 & 876 & 3,365 & Beef & 3,101 & Beef and Chicken \\
\hline 10 & 1,654 & 926 & 2,235 & Chicken & 1,628 & Chicken and Pork \\
\hline 11 & 827 & 1,286 & 1,390 & Pork & 4,389 & Beef* \\
\hline 12 & 881 & 1,041 & 1,394 & Chicken & 1,799 & Egg and Chicken \\
\hline 13 & 1,273 & 885 & 1,513 & Chicken & 3,577 & Beef and Pork \\
\hline 14 & 867 & 876 & 3,688 & Beef & 1,794 & Pork and Chicken \\
\hline 15 & 1,630 & 862 & 3,886 & Beef & 1,565 & Chicken and Pork \\
\hline 16 & 857 & 1,286 & 1,467 & Chicken & 3,267 & Beef and Chicken \\
\hline 17 & 905 & 1,041 & 3,348 & Beef & 3,583 & Beef and Chicken \\
\hline 18 & 1,251 & 885 & 1,413 & Fish & 3,421 & Beef and Chicken \\
\hline 19 & 856 & 951 & 1,523 & Chicken & 1,477 & Chicken and Pork \\
\hline 20 & 876 & 1,386 & 3,396 & Beef & 3,328 & Beef and Chicken \\
\hline 21 & 960 & 881 & 1,671 & Pork & 1,926 & Chicken and Pork \\
\hline 22 & 801 & 1,038 & 1,338 & Chicken & 3,385 & Beef and Fish \\
\hline 23 & 767 & 1,086 & 1,395 & Chicken & 3,530 & Beef and Chicken \\
\hline Mean & 1,103 & 1,026 & 2,179 & & 2,867 & \\
\hline
\end{tabular}

*Two options of beef dishes;

Source: Prepared by the authors (2019).

The results of diners' satisfaction and perceptions of the dishes/menus offered are shown in Table 3.

Table 3 | Opinion of diners about the foods/menus offered by two URs in the State of Paraná - 2019.

\begin{tabular}{|c|c|c|c|c|c|}
\hline \multirow{2}{*}{ Variable } & \multicolumn{2}{|c|}{$R \cup 1$} & \multicolumn{2}{|c|}{$R \cup 2$} & \multirow[t]{2}{*}{$p$} \\
\hline & $\mathrm{N}$ & $\%$ & $\mathrm{~N}$ & $\%$ & \\
\hline \multicolumn{6}{|c|}{ Satisfaction with the price paid } \\
\hline Very dissatisfied & 9 & 3.0 & 15 & 3.3 & \\
\hline Dissatisfied & 30 & 10.0 & 52 & 11.6 & 0.000 \\
\hline Satisfied & 63 & 21.0 & 324 & 72.0 & \\
\hline Very satisfied & 198 & 66.0 & 59 & 13.1 & \\
\hline
\end{tabular}




\begin{tabular}{|c|c|c|c|c|c|}
\hline \multirow{2}{*}{ Variable } & \multicolumn{2}{|c|}{$R \cup 1$} & \multicolumn{2}{|c|}{$R U 2$} & \multirow[t]{2}{*}{$p$} \\
\hline & $\mathrm{N}$ & $\%$ & $\mathrm{~N}$ & $\%$ & \\
\hline \multicolumn{6}{|l|}{ Satisfaction with the menu } \\
\hline Very dissatisfied & 40 & 13.3 & 80 & 17.8 & \multirow{4}{*}{0.43} \\
\hline Dissatisfied & 40 & 13.3 & 57 & 12.7 & \\
\hline Satisfied & 210 & 70.0 & 297 & 66.0 & \\
\hline Very satisfied & 10 & 3.3 & 16 & 3.6 & \\
\hline \multicolumn{6}{|l|}{$\begin{array}{l}\text { Satisfaction with respect for } \\
\text { eating habits }\end{array}$} \\
\hline Very dissatisfied & 6 & 2.0 & 50 & 11.1 & \multirow{4}{*}{0.000} \\
\hline Dissatisfied & 41 & 13.7 & 32 & 7.1 & \\
\hline Satisfied & 208 & 69.3 & 328 & 72.9 & \\
\hline Very satisfied & 45 & 15.0 & 40 & 8.9 & \\
\hline \multicolumn{6}{|c|}{ Satisfaction with the meat protein portion } \\
\hline Satisfied & 183 & 61.0 & 255 & 56.7 & \multirow{4}{*}{0.49} \\
\hline Dissatisfied - it should be larger & 105 & 35.0 & 174 & 38.7 & \\
\hline Dissatisfied - it should be smaller & 0 & 0.0 & 0 & 0.0 & \\
\hline Does not eat meat & 12 & 4.0 & 21 & 4.7 & \\
\hline \multicolumn{6}{|l|}{$\begin{array}{l}\text { Satisfaction with vegetarian } \\
\text { options }\end{array}$} \\
\hline Satisfied & 111 & 37.0 & 95 & 21.1 & \multirow{4}{*}{0.000} \\
\hline Dissatisfied - should be more varied & 33 & 11.0 & 62 & 13.8 & \\
\hline Dissatisfied - there are not any & 0 & 0.0 & 1 & 0.2 & \\
\hline Does not care & 156 & 52.0 & 292 & 64.9 & \\
\hline \multicolumn{6}{|l|}{ The UR purchases FF products } \\
\hline Yes & 45 & 15.0 & 18 & 4.0 & \multirow{3}{*}{0.000} \\
\hline No & 27 & 9.0 & 9 & 2.0 & \\
\hline Does not know & 228 & 76.0 & 423 & 94.0 & \\
\hline \multicolumn{6}{|l|}{ The UR purchases organic products } \\
\hline Yes & 48 & 16.0 & 28 & 28.0 & \multirow{3}{*}{0.000} \\
\hline No & 24 & 8.0 & 9 & 2.0 & \\
\hline Does not know & 228 & 76.0 & 413 & 91.8 & \\
\hline \multicolumn{6}{|l|}{ The menus are healthy } \\
\hline Yes & 240 & 80.0 & 333 & 74.0 & \multirow{3}{*}{0.065} \\
\hline No & 21 & 7.0 & 54 & 12.0 & \\
\hline Does not know & 39 & 13.0 & 63 & 14.0 & \\
\hline \multicolumn{6}{|l|}{ The menus are sustainable } \\
\hline Yes & 138 & 46.0 & 156 & 34.7 & \multirow{3}{*}{0.000} \\
\hline No & 53 & 17.7 & 48 & 10.7 & \\
\hline Does not know & 109 & 36.3 & 246 & 54.7 & \\
\hline
\end{tabular}

Source: Prepared by the authors (2019). 
We observed that there are differences between the URs in terms of satisfaction with the price paid, eating habits, and the offer of vegetarian options, as RU1 shows higher satisfaction than RU2 regarding these aspects. It is worth noting that RU1 has a greater diversity of ovolactovegetarian dishes (15). On this site, the highest percentage of vegetarian dishes is of textured soy protein (35\%), followed by vegetable-based dishes (26\%) and egg-based dishes (13\%). At RU2, however, only four variations of dishes were identified. The most commonly used ingredient was textured soy protein, $46 \%$, followed by egg-based dishes, with $29 \%$. These data might help explain the higher satisfaction of the RU1 diners with the vegetarian dishes.

\section{DISCUSSION}

When assessing the WF values of foods, it was found that vegetables have lower WF when compared to animal-based products. In this study, WF in the two sites was found to be proportionally lower whenever animal-based foods were reduced, especially red meat.

The data in this study corroborate the literature, demonstrating that lower environmental impacts are found in the plant-based food profile (HATJIATHANASSIADOU, 2019) and that omnivore menus' mean FW is up to $60 \%$ higher than vegetarian menus' mean (STRASBURG; JAHNO, 2015). This is easy to explain by considering that in the red meat production process it takes an average of three years to slaughter an animal and produce $200 \mathrm{~kg}$ of meat (net weight). It is stipulated that throughout its life, this animal consumed 1,300 kg of feed, 7,200 kg of forage, $24 \mathrm{~m}^{3}$ of water for drinking and $7 \mathrm{~m}^{3}$ of water for hygiene/slaughter procedures. Therefore, at the end of this process, $1 \mathrm{~kg}$ of beef has 15,500 litres of water embedded in its production. When comparing the WFs of $1 \mathrm{~kg}$ of beef and $1 \mathrm{~kg}$ of lettuce, beef's WF is 65 times higher than the vegetable's WF (TOM; FISCHBECK; HENDRICKSON, 2016).

It is also worth noting that with the types of meat offered in the omnivorous protein dish, beef was more relevant when compared to other used meats (pork, chicken and fish). According to GerbensLeenes, Mekonnen, and Hoekstra (2013), in general, beef has a larger total WF than pork, which in turn has a larger WF than poultry. As for the WF of fish, a study shows that this depends a lot on the type of fish and whether they are produced in farmed fish or at sea, with the second form having much smaller impacts (YUAN et al, 2017).

When comparing the WF of both URs, it was found that there was a difference in WF between the omnivore menus. This can be explained by RU2's strategy to offer two meat protein options with the main goal of reducing costs. However, this has a negative influence on the sustainability of the menu, with a higher WF than the RU1's respective menu.

In addition, even a greater frequency of red meat on the menu does not guarantee a higher level of satisfaction of RU2's diners regarding the price paid for the meal and the level of satisfaction with eating habits when compared to RU1. The price charged has a significant role in the users' perception, and satisfaction with this aspect allows an estimate of the access to food as an indicator of compliance with public policies and programs focused on this theme (IZEL; GASPAR; COSTA, 2016).

Dietary patterns centred on the consumption of animal-based products are correlated with higher levels of environmental impacts. Thus, food sustainability is found to be closely related to society's consumption profile (CARMO, 2017). For their part, consumers are placed as "choosers", with strong power to spread changes within market models. The opinion of consumers regarding sustainable consumption, specifically regarding meat, points out that the level of environmental awareness of individuals is a determinant that directly influences their food profile (BARONE; NOGUEIRA; GUIMARÃES, 2018; UNITED NATIONS SYSTEM STANDING COMMITTEE ON NUTRITION, 2017). 
For both sites, data reveal a significant percentage of those who express the desire for a larger portion of meat (about one-third of the diners). It is known that the consumption of meat per capita at the national level is above the recommended amount (CARVALHO, 2018; CARVALHO et al., 2016). and that this reflects the Brazilian food culture. It should be noted that the meat group is displayed noticeably on the menus because it is considered the "main dish". This practice should be reviewed and discussed because, although it considers the cultural dimension of sustainable diets, it clashes with their environmental dimension. Therefore, a balance point must be reached so that eating habits can be respected without causing environmental damage.

Another noteworthy finding when analyzing the opinion of diners is their lack of concern regarding the presence of vegetarian dishes on the menu. Studies show that the intention to reduce meat consumption as a justification for environmental sustainability is still low among consumers (BARONE; NOGUEIRA; GUIMARÃES, 2018; CARVALHO, 2018). On the national scene, some initiatives to address the issue within the URs can be identified, such as the Segunda Sem Carne ("Meat-free Monday") campaign, which proposes the removal or reduction of meat consumption at least one day a week, presumably on Monday (UNIVERSIDADE FEDERAL DO RIO GRANDE DO SUL, 2019).

A lower percentage of vegetarian consumers and/or adherents of the meatless profile indicate satisfaction with the variety of dishes. A higher level of satisfied diners at RU1 compared to RU2 may be related to menu planning. At RU1 menu planning is monthly, thus it has a higher level of flexibility for the inclusion of items according to the seasonality, while RU2's planning has less flexibility. It appears that the lower variety of dishes at RU2 resulted in a higher percentage of diners pointing out the need to improve it compared to RU1.

However, it is important to consider that most vegetarian dishes are soy-based and that there are controversial issues in this regard not only because of the number of pesticides used in such crop but also because it is predominantly transgenic (MESSINA; BURKE, 2017). In addition, consumption of this commodity reflects the homogenization of food, loss of food diversity, environmental pollution, and social exclusion (AZEVEDO, 2011). Even a decade and a half after the beginning of the planting of transgenic soy in Brazil, there are different positions on the existence of risks to human health. It is imperative to consider that there is a strong game of power and political and economic interests that prevail in debates advocating its cultivation, as well as obscurantism regarding these reflections. However, it is undeniable that transgenics are not included in any production paradigm considered ecologically or socially sustainable (CORTESE et al., 2018).

The transition to a more sustainable food profile is a complex process, strongly rooted in social, cultural and economic aspects. However, reducing the consumption of animal-based products is a crucial aspect to achieve healthier and more sustainable diets, and the improvement of this situation, among other factors, is linked to the consumption profile that society establishes (CERUTTI, 2017).

Thus, this study reveals that this population's awareness and knowledge about food sustainability is at an early stage since most of them are unaware of the origin of the food they consume (whether it comes from family farming - FF - or not), as well as its characteristics (organic or not), and whether the menus offered are sustainable. In the context of RU1, the lower percentages of unawareness may be related to the fact that the University itself has environment and food and nutritional security as a premise. And, more specifically, the UFFS's Laranjeiras do Sul campus has a Postgraduate Program in Agroecology and Sustainable Rural Development, and the theme emerges in discussions about the UR's operation.

Thus, it is necessary to consider that the act of placing the power in consumers' hands may reflect the increase of their authority, the reappropriation of knowledge and skills that can be implemented in their daily life practices (PORTILHO, 2015), leading to their claiming for more sustainable dietary patterns.

However, moving this discussion only to the field of consumption would be like transferring responsibility and regulatory action to the private sphere and seeking solutions to collective problems at the individual 
level. Therefore, advancements are desired, and to go through this path it is important not only to ensure there are spaces to discuss the theme and encourage consumers' reflections but also to debate the issue with larger spheres, both public and private (CERUTTI, 2017; OLIVEIRA; JAIME, 2016).

\section{FINAL CONSIDERATIONS}

At the general level, there is no difference in water footprint between the menus of the two URs investigated. However, when comparing their omnivore menus, a difference in WF was evidenced. The strategy adopted by RU2 to reduce costs harms the sustainability of the menu, which has a higher WF.

Differences in water footprint were also evidenced between omnivore and vegetarian menus, which corroborates the literature and suggests revisions in the quantity and frequency of meat available in the menus, especially red meat. Therefore, one of the indications of this study is that the professionals responsible for preparing the menus of university restaurants offer more meat such as chicken and fish, reducing red meat. In addition to the review of omnivorous menus, more vegetarian options besides soy protein should be considered, seeking to meet nutritional needs, but also the diversification of menus with the addition of other vegetable sources such as unconventional food plants, for example. Therefore, enabling the cooks for these new preparations is necessary.

On the other hand, it is necessary to work with consumers so that they also seek to change their eating practices towards health and sustainability. This survey sought to understand a little more the opinions of diners on these aspects. Again, differences were found between the restaurants. In RU1 the consumers reveal greater satisfaction with the price paid and with vegetarian options as well as greater awareness of purchases of FF products and organic products. Their responses were also more affirmative regarding the sustainability of the menus offered in the UR. However, in both units, a small number of vegetarian diners was identified, while a large share of respondents, conversely, would like to have a bigger meat protein portion.

Based on these findings, we conclude that RU1 was more compliant than RU2 with the criteria used here for a sustainable diet assessment. However, it does not mean that RU1 can be regarded as a role model. Both sites proved to need adjustments in their collective catering to reduce WF and encourage actions that elicit diners' behaviours, like food education campaigns, towards sustainability.

Public food programs must be conducive to good environmental practices. In this sense, this study assumes that the State can be an essential actor in changing eating practices when it seeks to offer meals that have a smaller environmental impact, in addition to being nutritious. Considering that the public served is university students, these changes can be leveraged, aligning this offer to the environmental and nutritional discussions that the academic context can provide. Therefore, these places can be used for the transition to more sustainable diets and the mitigation of climate change and the rational use of natural resources.

Finally, one of the limitations of this study is the use of international WF references. This can be considered a limitation because it does not necessarily reflect the reality of the water use of food produced in the country. However, so far there are not many studies that have used methodologies such as life cycle analysis to determine the WF of Brazilian foods which need to be changed with more research on this.

It seems likely that, as the sites investigated, other URs in Brazil may have similar indicators. However, it is necessary to carry out more studies to investigate different aspects of food sustainability, especially in places funded by public entities, to reallocate resources to make not only healthy but also sustainable food available to the population. 


\section{REFERENCES}

AZEVEDO, E. de. Riscos e controvérsias na construção social do conceito de alimento saudável: o caso da soja. Revista de Saúde Pública [on-line], v. 45, n. 4, p.781-788, 2011. Available at: https://doi.org/10.1590/S003489102011000400019. Accessed on: 7 jun. 2021.

BARILLA CENTRE FOR FOOD \& NUTRITION. Double pyramid 2015, recommendations for a sustainable diet. 2015.

BARONE, B. et al. Sustainable diet from the urban Brazilian consumer perspective. Food Research International, 2018. https://doi.org/10.1016/j.foodres.2018.05.027

BRANDÃO, C. R. P. Contabilização da pegada hídrica azul, verde e cinza da rizicultura no perímetro irrigado Betume/SE. São Cristóvão - SE. Universidade Federal de Sergipe, 2020.

CARMO, R. L. et al. Água virtual e desenvolvimento sustentável: o Brasil como grande exportador de recursos hídricos. XXV CONGRESO DE LA ASOCIACIÓN LATINO AMERICANA DE SOCIOLOGIA. Porto Alegre, 2017.

CARVALHO, A. M. et al. Excessive red and processed meat intake: relations with health and environment in Brazil. The British journal of nutrition, 2016, v. 115, n. 11, p. 2011-2016.

CARVALHO, A. M. Tendência Temporal no consumo de carne no município de São Paulo: estudo de base populacional, 2012, 80 p. Nutrição em Saúde Pública. Universidade de São Paulo. São Paulo, 2018.

CERUTTI, A. et al. Environmental sustainability of traditional foods: the case of ancient apple cultivars in Northern Italy. Journal of Cleaner Production, v. 52, p. 245-252, 2017.

CORTESE, R. D. M. et al. A label survey to identify ingredients potentially containing GM organisms to estimate intake exposure in Brazil. Public Health Nutrition 2018. https://doi.org/10.1017/S1368980018001350

FOOD AND AGRICULTURE ORGANIZATION. Sustainable diets and biodiversity: directions and solutions for policy, research and action. Rome. 2014. Available at: http://117.239.19.55:8080/xmlui/bitstream/ handle/123456789/169/pdf698.pdf?sequence=1\&isAllowed=y Accessed on: 5 jun. 2021.

GARZILLO, J. M. F. A alimentação e seus impactos ambientais: abordagens dos guias alimentares nacionais e estudo da dieta dos brasileiros. Tese (Doutorado). São Paulo: Faculdade de Saúde Pública, 2018.

GERBENS-LEENES, P. W.; MEKONNEN, M. M.; HOEKSTRA, A. Y. The water footprint of poultry, pork and beef: a comparative study in different countries and production systems. Water Resources and Industry, v. 1, n. 2, p. 2536, 2013.

HATJIATHANASSIADOU, M. S. et al. Environmental Impacts of University Restaurant Menus: a case study in Brazil. Sustainability. 2019. Available at: file:///C:/Users/madalozzo3/Downloads/sustainability-11-05157.pdf. Accessed on: jan. 2019.

HOEKSTRA, A. Y. Virtual water trade: proceedings of the international expert meeting on virtual water trade. $n$. 12, Delft: Unesco-IHE, 2003. 239 p.

IZEL, P. A.; GASPAR, L. P.; COSTA, G. V. Percepção dos usuários sobre a prestação dos serviços de um Restaurante Universitário de uma universidade pública da Região Norte do Brasil. Revista Científica Interdisciplinar, v. 1, n. 3, p. 63-78, 2016.

MARTINELLI, S. S.; CAVALI, S. B. Alimentação saudável e sustentável: uma revisão de narrativa sobre desafios e perspectivas. Revista Ciência e Saúde Coletiva. 2019. https://doi.org/10.1590/1413-812320182411.30572017

MASON, P.; LANG, T. Sustainable Diets: how ecological nutrition can transform consumption and the food system. London: Routledge, 2017.

MEKONNEN, M. M.; HOEKSTRA, A. Y. The green, blue and grey water footprint of crops and derived crops products. Hydrology and Earth System Sciences, v. 15. 2011. 
MESSINA, V. K.; BURKE, K. I. Position of the American Dietetic Association: vegetarian diets. Journal of the American Dietetic Association, v. 97, p. 1317- 1321, 2017.

OLIVEIRA, N. R. F.; JAIME, P. C. O encontro entre o desenvolvimento rural sustentável e a promoção da saúde no Guia Alimentar para a População Brasileira. Revista Saúde e Sociedade, v. 25, n. 4, p. 1108-1121. São Paulo, Brasil, 2016.

PORTILHO, F. Consequências Políticas do deslocamento da questão ambiental para o campo do consumo. In: Sustentabilidade ambiental, Consumo e Cidadania. p. 163-197, São Paulo. 2015.

STRASBURG, V.; JAHNO, V. D. Sustentabilidade de cardápio: avaliação da pegada hídrica nas refeições de um restaurante universitário. Rev. Ambient. Água, v. 10, n. 4, p. 903-914, 2015. ISSN 1980-993X. http://dx.doi. org/10.4136/ambi-agua.1664.

TOM, M. S.; FISCHBECK, P. S.; HENDRICKSON, C. T. Energy use, blue water footprint, and greenhouse gas emissions for current food consumption patterns and dietary recommendations in the US. Environment Systems \& Decisions, v. 36, n. 1, p. 92-103, 2016.

TRICHES, R. M. Sustainable diets: definition, state of the art and perspectives for a new research agenda in Brazil. Ciencia e Saúde Coletiva, v. 26, n. 5, p. 1833-1846, 2021.

TRICHES, R. M. Dietas saudáveis e sustentáveis no âmbito do sistema alimentar no século XXI. Saúde Debate, v. 44, n. 126, p. 883-896, 2021.

TRICHES, R. M.; SCHNEIDER, S. Alimentação, sistema agroalimentar e os consumidores: novas conexões para o desenvolvimento rural. Cuadernos de Dessarrolo Rural, v. 12, 2015.

UNITED NATIONS SYSTEM STANDING COMMITTEE ON NUTRITION. Sustainable Diets for Healthy People and a Healthy Planet. 2017. Available at: https://www.unscn.org/uploads/web/news/document/Climate-NutritionPaper-EN-WEB.pdf. Accessed on: 6 jun. 2021.

UNIVERSIDADE FEDERAL DO RIO GRANDE DO SUL. RUs realizam enquetes sobre campanha Segunda sem Carne. Available at: https://www.furg.br/en/notices/rus-realizam-enquete-sobre-segunda-sem-carne. Accessed on: sep. 2019.

YUAN, Q. et al. Water footprint of feed required by farmed fish in China based on a Monte Carlo-supported von Bertalanffy growth model: a policy implication. Journal of Cleaner Production, v. 153, p. 41-50, 2017. Available at: https://doi.org/10.1016/j.jclepro.2017.03.134. 